
\title{
educação revista
do centro de

\section{As implicações do Programa de Residência Pedagógica para formação docente: das narrativas à (re)elaboração do trabalho pedagógico no ensino da Educação Física}

\author{
The implications of the Pedagogical Residency Program for teacher \\ formation: from narratives to (r)elaboration of pedagogical work in \\ Physical Education teaching
}

Kleber Tüxen Carneiro

Docente da Universidade Federal de Lavras. Lavras, Minas Gerais, Brasil.

kleber2910@gmail.com - http://orcid.org/0000-0003-0826-6172

Bruno Adriano Rodrigues da Silva

Docente da Universidade Federal do Estado do Rio de Janeiro. Rio de Janeiro, Rio de Janeiro, Brasil. b.adriano_rs@yahoo.com.br - https://orcid.org/0000-0002-0772-2503

Fábio Pinto Gonçalves dos Reis

Docente da Universidade Federal de Lavras. Lavras, Minas Gerais, Brasil.

fabioreis@ufla.br - https://orcid.org/0000-0003-4797-5895

Recebido em 19 de fevereiro de 2020

Aprovado em 15 de janeiro de 2021

Publicado em 30 de junho de 2021

\section{RESUMO}

O artigo cotejou as implicações do Programa Residência Pedagógica (desenvolvido no núcleo de Educação Física, sob os cuidados de uma instituição de educação superior federal), em relação à formação continuada e a organização do trabalho pedagógico desenvolvido por três (3) docentes atuantes em escolas públicas, numa cidade sul mineira. Tratou-se de uma investigação de natureza qualitativa, sob um desenho narrativo. Quanto aos procedimentos metodológicos, utilizou-se para a coleta de dados, entrevistas com base em questionário semiestruturado, com efeito, explorando o significado das ações desses docentes, a partir do teor narrativo que expuseram. Para erigir as categorias de análise, empregou-se a técnica de triangulação dos dados, observando, no primeiro processo interpretativo, a valorização fenomênica e a técnica dos dados primários, em seguida, num segundo movimento perscrutador, as informações foram contextualizadas, criticadas, comparadas e trianguladas. Por fim, na qualidade de última ação analítica, formulamos três categorias de análise, relacionando o conteúdo das entrevistas e a literatura pertinente. Os resultados evidenciaram que o programa fora auspicioso, em virtude de suas especificidades e de sua organização pedagógica, notadamente em relação à proposta de planificação dos conteúdos. De igual modo, demonstraram 


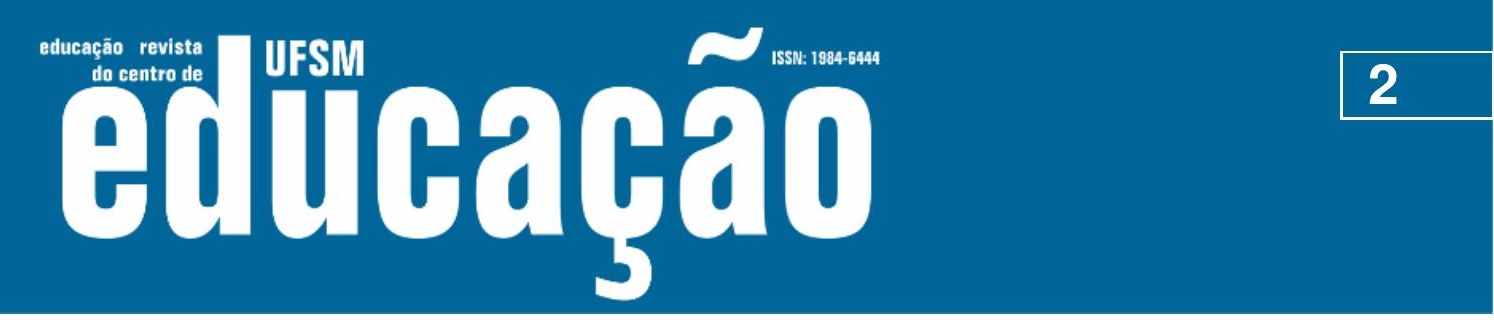

ISSN: 1984-6444 | http://dx.doi.org/10.5902/1984644442561

que os depoentes desfrutaram de formações distintas e encontravam-se em momentos díspares da carreira docente. Além disso, revelaram também que a formação continuada, proporcionada no interior do referido programa, suscitou interação (formativa) entre a educação básica e a superior, por efeito, pode-se rechaçar a dicotomia entre teoria e prática pedagógica, o que por sua vez afetou a disposição e o desdobramento do trabalho pedagógico realizado pelos pesquisados.

Palavras-chave: Programa Residência Pedagógica; Formação Continuada; Educação Física; Trabalho Pedagógico.

\section{ABSTRACT}

The article checked the implications of the Pedagogical Residency Program (developed in the Physical Education nucleus, under the care of a federal higher education institution), in relation to continuing formation and the organization of pedagogical work developed by three (3) teachers working in public schools in a southern Minas Gerais city. It was treated a qualitative investigation, under a narrative design. As for the methodological procedures, interviews based on a semistructured questionnaire were used for data collection, in fact, exploring the meaning of the actions of these teachers, based on the narrative content they exposed. To erect the analysis categories, the data triangulation technique was used, observing in the first interpretative process, the phonetics and technical valuation of the primary data, then, in a second analytical movement, the information was contextualized, criticized, compared and triangulated. Finally, as the last analytical action, we formulate three specific categories of analysis, relating the content of the interviews and the relevant literature. The results showed that the program was auspicious, due to its specificities and pedagogical organization, notably in relation to the content planning proposal. In the same way, demonstrated that the interviewees obtained distinct formations and experience different moments in teaching career. In addition, it also revealed, that the continuing formation provided within the aforementioned program gave raised to (formative) interaction between basic and higher education, by effect, one can refuse the dichotomy between theory and pedagogical practice, which in turn affected the disposition and unfolding of the pedagogical work carried out by the respondents.

Keywords: Pedagogical Residence Program; Continuing Formation; Physical Education; Pedagogical work. 


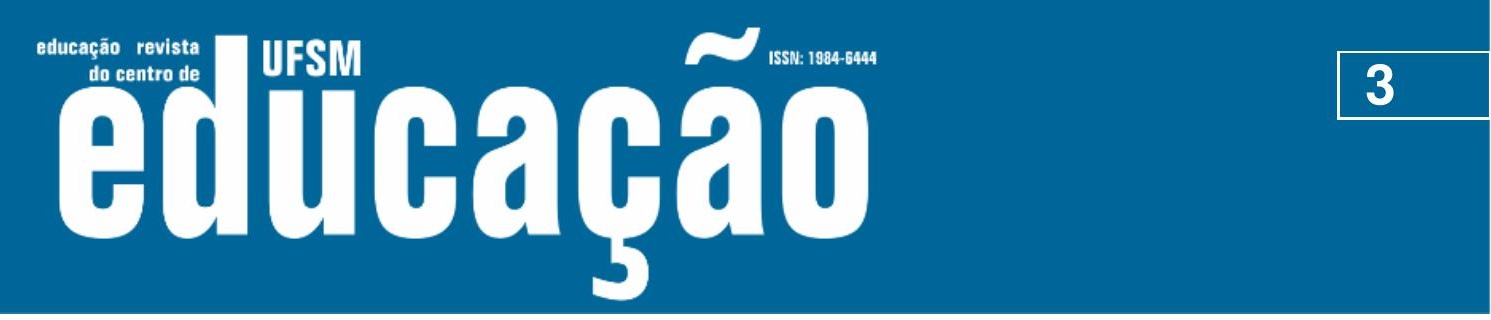

ISSN: 1984-6444 | http://dx.doi.org/10.5902/1984644442561

\section{Introdução}

A formação de professores tem sido um campo de investigação sistemática, notadamente a partir dos anos 1990, conforme anotou Couto (2015). Desde então, pesquisas relativas à formação - inicial e continuada - de professores têm sido dedicadas a compreender como se constitui e desenvolve a identidade/carreira de um docente, sendo que algumas delas inclinam-se a desvelar os conhecimentos que - por suposto - os futuros professores desenvolvem para ensinar (PONTE \& CHAPMAN, 2008). São estudos que versam sobre questões relativas ao professor e à sua formação (BULLOUGH e GITTLIN, 2001; LOUGHRAN, 2006; SEGALL, 2002; SHULMAN, 1986).

Oliveira e Hannula (2008, p. 16), contudo, glosam que no rol dos autores supracitados, alguns (erroneamente) desconsideram "as perspectivas dos futuros professores sobre o que estão a aprender e como [o fazem], do mesmo modo que não explicam o desenvolvimento de tal conhecimento", tendo em vista as suas experiências pregressas.

Nesse sentido, as investigações sinalizam que aprender a ensinar compreende um processo complexo e multidimensional que depende, em grande medida, da capacidade de sintetizar, integrar, correlacionar e aplicar os conhecimentos provenientes de várias fontes, na construção de uma compreensão sobre como facilitar a aprendizagem em contextos dinâmicos e repleto por uma multiplicidade de aspectos (COUTO, 2015).

Os contributos das pesquisas supracitadas têm respondido, em parte, a alguns dos dilemas e desafios que afetam a formação de professores, eis, portanto, uma das justificativas para levar a cabo nosso empreendimento científico. Trata-se de um cenário que se torna ainda mais abstruso quando se refere à esfera da formação continuada - ou em serviço, como preferem alguns especialistas do assunto - uma vez que, conforme explana Demo (2008, p. 40): "é preciso consertar o avião em pleno vôo". Em outras palavras, é preciso colmatar as fragilidades formativas ao longo do desenvolvimento do trabalho docente. 


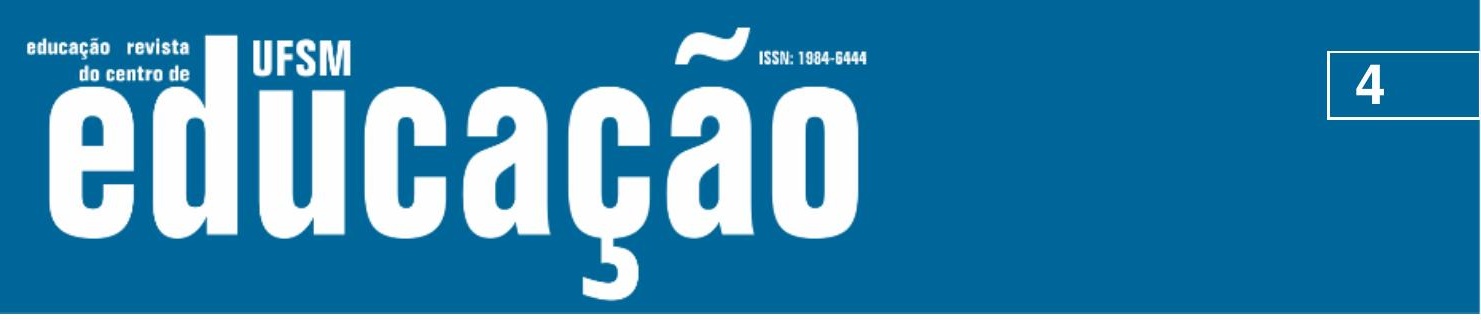

ISSN: 1984-6444 | http://dx.doi.org/10.5902/1984644442561

Quiçá o leitor possa estar interrogando-se sobre as razões pelas quais a formação continuada figura como um tema desafiador? Pois bem, Demo (2008, p. 40), ao esclarecer o uso da metáfora apresentada no parágrafo anterior, expõe, em certa medida, a complexidade do quadro, vejamos em seus dizeres: "O problema mais agudo é que traduzimos na formação permanente os mesmos vícios da original, encurtando os cursos a alguns dias ou menos, em ambientes marcadamente instrucionistas" (grifo nosso).

Em relação às nomenclaturas concernentes às modalidades de formação continuada ou permanente, deve-se compreender que são reflexos de um contexto histórico, conforme pondera Alvarado-Prada, et al. (2010). São nomenclaturas que, na maioria dos casos, desdobram-se e materializam-se em propostas cujos formatos dar-se-ão em: cursos, palestras e oficinas, como canal para (in)formar professores em um processo contínuo.

Se não bastasse a conjuntura antes exposta, tem-se, além disso, questões relativas às políticas educacionais que, por vezes, traduzem a usurpação política e partidária, como bem destacou e advertiu Saviani (2010), ao associar o termo "zigue-zague" a essa constante modificação de programas educacionais em decorrência da troca de legendas no comando das gestões dos diferentes entes federativos. Isso, sem dúvida, vilipendia os programas educacionais que em alguns casos terminam inacabados, isto é, sem ao menos concluir o ciclo pensado para sua concretização.

De tal modo que, esse quadro desafiador e intrigante engendrou esta investigação, a qual se propôs cotejar as implicações do Programa Residência Pedagógica (PRP) na formação continuada de professores - cognominados no interior do referido programa de preceptores - no tocante à acepção e à organização do trabalho pedagógico desenvolvido na disciplina de Educação Física, em suas instituições escolares de origem. Trata-se de um programa que foi desenvolvido em uma universidade federal do sul do estado de Minas Gerais, conforme os detalhes que serão apresentados na seção ulterior

Para tanto, realizou-se uma pesquisa sob os pressupostos qualitativos (LUDKE; ANDRÉ, 1986). Quanto à abordagem da pesquisa, trata-se de um desenho 


\section{Autนaดูลิ}

ISSN: 1984-6444 | http://dx.doi.org/10.5902/1984644442561

narrativo, dado que investigações com este enfoque dizem respeito "às histórias de vidas e experiências de algumas pessoas para descrevê-las e analisá-las. O que interessa são os próprios indivíduos e o ambiente que os rodeia" (SAMPIERl; COLLADO; LUCIO, 2013, p. 509).

No que concerne aos participantes, o estudo contou com a participação de duas professoras e um professor, ou seja, três (3) participantes, sendo que o critério de escolha dos mesmos derivou de três atributos, quais sejam: o primeiro em razão do delineamento do estudo, visto que o desígnio seria observar os desdobramentos do PRP no interior da disciplina de Educação Física; na condição de segundo critério, tem-se o fato que os (3) docentes participantes desta pesquisa representam o total de preceptores que compõem o núcleo de formação da disciplina Educação Física, em que a experiência formativa (que emoldura a pesquisa) sucedeu; e o terceiro e último vetor que conduziu-nos a escolhê-los guarda relação com a diversidade de instituições, uma vez que cada um deles atua em uma unidade escolar pública diferente, situadas em um município localizado ao sul do Estado de Minas Gerais.

Soma-se a isso, o fato de atuarem em etapas de ensino distintas - o professor pesquisado restringe-se à atuação no Ensino Médio, uma das professoras coaduna o trabalho na Educação Infantil e Ensino Fundamental (anos iniciais) e a outra se dedica aos anos iniciais e finais do Ensino Fundamental - uma conjuntura sobre a qual permitiu-nos verificar as implicações desse programa em todas as etapas da educação básica, adjudicando, assim, um panorama auspicioso para cotejar seus possíveis efeitos.

Doravante apresentar-nos-emos o referido programa, assim como sua organização no núcleo em que se desenvolveu a pesquisa.

\section{O Programa Residência Pedagógica}

Bem, como dissemos esta seção destina-se a apresentar a estrutura e prerrogativas do PRP, assim como discorrer sobre as particularidades do grupo no qual o trabalho pedagógico foi realizado. 


\section{T Hesm

ISSN: 1984-6444 | http://dx.doi.org/10.5902/1984644442561

Evidentemente que os limites (temporais e espaciais) não permitirá uma descrição detalhada de todo o programa, contudo, o que se pretende corresponde a uma descrição geral, tal e qual a do núcleo no interior do departamento de Educação Física de uma Universidade Federal em terras sul mineiras, conforme citado na introdução.

Nesse sentido, quatro são os objetivos do PRP, segundo o site da Coordenação de Aperfeiçoamento de Pessoal de Nível Superior (CAPES), a saber:

1. Aperfeiçoar a formação dos discentes de cursos de licenciatura, por meio do desenvolvimento de projetos que fortaleçam o campo da prática e conduzam o licenciando a exercitar de forma ativa a relação entre teoria e prática profissional docente, utilizando coleta de dados e diagnósticos sobre o ensino e a aprendizagem escolar, entre outras didáticas e metodologias;

2. Induzir a reformulação da formação prática nos cursos de licenciatura, tendo por base a experiência da residência pedagógica;

3. Fortalecer, ampliar e consolidar a relação entre a IES e a escola, promovendo sinergia entre a entidade que forma e a que recebe o egresso da licenciatura e estimulando o protagonismo das redes de ensino na formação de professores;

4. Promover a adequação dos currículos e propostas pedagógicas dos cursos de formação inicial de professores da educação básica às orientações da Base Nacional Comum Curricular (BNCC). (CAPES, 2019).

Dos objetivos anteriormente expostos, os três primeiros parecem-nos melhor direcionados e preocupados em responder aos desafios formativos que afetam a profissão docente, haja vista a dicotomia historicamente situada entre teoria e prática, um mote que receberá atenção ulteriormente. Já o quarto, ao que parece, destoa dos demais, visto que, apesar de fazer referência à adequação das questões das matrizes pedagógicas dos cursos de formação inicial de professores, tal como a Base Nacional Comum Curricular ${ }^{1}$, não se trata de superar os desafios históricos colocados para as mesmas.

Em relação à dinâmica de participação do referido programa, a portaria CAPES № 175 de 7 de agosto de 2018, no artigo 4, descreve-a do seguinte modo: 


\section{usm

ISSN: 1984-6444 | http://dx.doi.org/10.5902/1984644442561

I - Residente: para discentes com matrícula ativa em curso de licenciatura que tenham cursado o mínimo de $50 \%$ do curso ou que estejam cursando a partir do $5^{\circ}$ período;

II - Coordenador institucional: para docente da IES responsável pelo projeto institucional de Residência Pedagógica;

III - Docente orientador: para o docente que orientará o estágio dos residentes estabelecendo a relação entre teoria e prática;

IV - Preceptor: para o professor da escola de educação básica que acompanhará os residentes na escola-campo. (CAPES, 2018).

Cabe ressaltar que para todos os envolvidos há incentivo de bolsas, variando, conforme a atribuição de cada participante, excetuando àqueles que aderiram voluntariamente à participação.

No que concerne às atribuições daqueles que compõem o programa, há distintas responsabilidades para cada um dos segmentos envolvidos no trabalho pedagógico. Para gestão didático-pedagógica (Coordenador Institucional) do PRP, espera-se, de modo geral, a "elaboração do projeto institucional e o plano de atividades dos alunos articulado com os normativos do estágio supervisionado da IES (CAPES, 2018)". Embora existam outras responsabilidades descritas no referido edital, elas estariam contidas, de certa maneira, nessa diretriz mais ampla. Enquanto que ao Docente orientador cabe a função de:

b) elaborar, desenvolver e acompanhar as atividades de orientação e preceptoria do subprojeto, inclusive articulando-se com outros docentes orientadores da IES e/ou das disciplinas de estágio curricular supervisionado, visando estabelecer uma rede institucional colaborativa para aperfeiçoar a formação prática nas licenciaturas. (CAPES, 2018).

O edital faz alusão ao desempenho de outras atividades, contudo, contempladas na descrição anterior, de alguma forma. Sob a responsabilidade do Preceptor, estaria:

“a) Participar do curso de formação de preceptores, b) auxiliar o docente orientador na orientação do residente quanto à elaboração do seu Plano de Atividade; c) acompanhar e orientar as atividades do residente na escolacampo, zelando pelo cumprimento do Plano de Atividade". (CAPES, 2018). 


\section{工

ISSN: 1984-6444 | http://dx.doi.org/10.5902/1984644442561

Tal como no caso dos demais participantes do programa, caberiam outros encargos aos professores (preceptores) que recebem os discentes (residentes), no entanto, estariam eles englobados nas atribuições arroladas antes.

Quanto ao residente, competem as seguintes solicitações:

a) elaborar seu plano de atividades em conjunto com docente orientador e o preceptor;

b) cumprir a carga horária mínima 440 (quatrocentos e quarenta) horas de residência estabelecido nesta Portaria;

c) desenvolver as ações do plano de atividades com assiduidade e de forma acadêmica, profissional e ética;

d) elaborar e entregar os relatórios previstos no prazo estabelecido no plano de atividade. (CAPES, 2018).

Ademais, há outras ocupações designadas aos discentes que participam do PRP, entretanto, subentendidas naquelas que foram descritas anteriormente.

Pois bem, feita, então, essa exposição mais ampla do programa, passaremos para uma breve descrição do mesmo no interior da instituição federal, na qual o PRP acontece.

$\mathrm{Na}$ referida Instituição de Ensino Superior (IES), o programa conta com a composição de seis (6) subprojetos, agrupados em quatro (4) núcleos, quais sejam: Subprojeto Educação Física; Subprojeto Letras; Subprojeto Multidisciplinar (núcleo 1) e (núcleo 2); Subprojeto Pedagogia (núcleo 1) e (núcleo 2).

Há um coordenador institucional em âmbito geral da IES, dois docentes orientadores para cada núcleo, três preceptores e de 24 a 30 residentes, visto que alguns núcleos dispõem de residentes voluntários, enquanto outros não.

São realizadas reuniões periódicas, a fim de delinear o trabalho pedagógico mais amplo, contudo, os encaminhamentos e decisões de fórum didático/pedagógico ficam sob a condução de cada área específica, tendo em vista as idiossincrasias epistemológicas, em que pese haver um "eixo comum", a saber: a formação de professores.

Portanto, após discorrermos as questões mais amplas do programa, assim como os aspectos mais gerais de seu funcionamento nos domínios da IES federal 


\section{Autนaดูลิ}

ISSN: 1984-6444 | http://dx.doi.org/10.5902/1984644442561

em questão, doravante, expô-lo-emos as características do núcleo no qual a pesquisa, que ora apresentamos, ocorreu.

Trata-se, assim, do subprojeto ao abrigo do curso de licenciatura em Educação Física. Sua composição, em partes é análoga a dos demais núcleos, porém, conta com algumas idiossincrasias. Uma delas é o fato de desfrutar de três docentes orientadores, sendo que um deles é voluntário, condição que difere dos demais núcleos, visto que tal atribuição aumenta a jornada de trabalho, fato insólito e que merece registro.

Outro aspecto que faz jus a alusão diz respeito à composição de membros das reuniões em que se desenvolve o trabalho pedagógico, considerando que congrega professores (em exercício docente) e alunos voluntários, interessados no conteúdo formativo ali apregoado.

Destacamos, ainda, a ocorrência de que em alguns encontros houve a confluência entre os dois programas institucionais, cujo curso de licenciatura em Educação Física desfruta, sendo eles: o Programa Institucional de Bolsa de Iniciação à Docência (Pibid) e o PRP, já que o primeiro reúne alunos dos quatro primeiros períodos do curso de licenciatura, enquanto que o outro conta com alunos dos quatro últimos períodos do curso.

Em termos teórico/metodológicos, o trabalho formativo desenvolvido no núcleo em questão dividiu-se em quatro eixos epistemológicos, quais sejam: 1) epistemologia da prática profissional docente; 2) escola e sua função social; 3) delineamento - histórico e conceitual - da Educação Física e seu(s) objetivo(s) epistemológico(s); e 4) diálogos sobre a didática geral e a didática aplicada ao campo da Educação Física escolar.

Feita essa breve contextualização, passamos a estrutura metodológica da pesquisa.

\section{Delineamento Metodológico}

A investigação assenta-se sob os pressupostos qualitativos, tendo em vista que pesquisas dessa natureza buscam, sobretudo, as questões internas - os 


\section{Authaดูã}

ISSN: 1984-6444 | http://dx.doi.org/10.5902/1984644442561

aferentes afetivos que produzem e instituem narrativas e discursos - referentes à subjetividade/objetividade humana (LUDKE; ANDRÉ, 1986).

Ao mencionar os benefícios da pesquisa qualitativa, Sampieri; Collado; Lucio (2013, p.102) elucidam que esta é uma investigação que pretende cotejar informações de maneira independente "ou conjunta sobre os conceitos ou as variáveis a que se referem. Logo, podem integrar as medições ou informação de cada uma das variáveis ou conceitos para dizer como é e como se manifesta o fenômeno de interesse".

Quanto à abordagem da pesquisa, trata-se de um desenho narrativo, dado que investigações com enfoque narrativo dizem respeito às "histórias de vidas e experiências de algumas pessoas para descrevê-las e analisá-las. O que interessa são os próprios indivíduos e o ambiente que os rodeia" (SAMPIERI; COLLADO; LUCIO, 2013, p.509). Trata-se, portanto, de um delineamento, geralmente, utilizado na direção de conferir uma sucessão de acontecimentos, fornecendo uma espécie de quadro microanalítico (CRESWELL, 2009).

Participaram da pesquisa três (3) docentes, sendo duas professoras e um professor, conforme já exposto na introdução, convindo reiterar. Por questões éticas e de respeitabilidade aos entrevistados, suprimimos a identidade dos mesmos, sendo que a título de identificação foram nomeados de PE 1, PE 2 e PE 3, porquanto a sigla traduz a compilação: Professor/as Entrevistadas. Todos os pesquisados manifestaram aquiescência, por intermédio do termo de consentimento livre e esclarecido, em relação à sua participação na pesquisa, a qual foi aprovada pelo comitê de Ética em Pesquisa com Seres Humanos de uma IES sul mineira (CAAE: 22479219.0.0000.5148)

Para a coleta dos dados recorremos a um roteiro de entrevista semiestruturado, no qual constavam três (3) eixos norteadores, a saber: o primeiro relativo aos dados pessoais e à trajetória formativa dos depoentes; o segundo cotejou os efeitos do Programa de Residência Pedagógica para a escola, de modo geral; e o terceiro eixo observou as implicações do programa nas aulas de Educação Física, assim como para formação docente. 


\section{Autนaดูลิ}

ISSN: 1984-6444 | http://dx.doi.org/10.5902/1984644442561

A despeito de a pesquisa ter sido pensada no interior do núcleo de Educação Física pertencente ao PRP em uma IES, as entrevistas ocorreram no interior das unidades escolares, nas quais os depoentes atuam na condição de docentes.

Após as entrevistas, realizamos a transcrição "bruta", sendo que empós uma primeira leitura mais criteriosa, notou-se a necessidade de se textualizar o material transcrito, sem, no entanto, alterar seu conteúdo, ou seja, seu sentido e significado. O tempo total para a realização de todas as entrevistas, registrado em nossas gravações, somou 1 hora, 55 minutos e 32 segundos (1:55'32').

$\mathrm{Na}$ condição de recurso analítico para análise qualitativa dos dados, empregamos a técnica da triangulação, uma vez que ela consiste numa "estratégia de pesquisa que se apoia em métodos científicos testados e consagrados, servindo e adequando-se a determinadas realidades, com fundamentos interdisciplinares" (MINAYO et al., 2010, p. 71).

Assim, no primeiro processo interpretativo, fez-se "uma valorização fenomênica e técnica dos dados primários, em si mesmos e à exaustão" (GOMES et al., 2010, p. 185), mediante às seguintes etapas: 1) preparação e reunião dos dados; 2) avaliação da qualidade e, por último, 3) primeiro esboço de potenciais categorias de análise. Posteriormente, num segundo movimento perscrutador, as narrativas provenientes das entrevistas foram "contextualizadas, criticadas, comparadas e trianguladas" (GOMES et al., 2010, p. 185). Em outras palavras, adequamos o delineamento esboçado na etapa anterior, ao passo de eliminar redundâncias, estabelecer correlações e possíveis ilações.

Por fim, na qualidade de última ação analítica, formulamos três categorias de análise, relacionando o conteúdo das entrevistas e a literatura pertinente, conforme se verá de agora em diante. 


\section{Hsm

Características dos docentes, formação inicial e motivação para o exercício da profissão docente na Educação Física

$\mathrm{Na}$ tabela a seguir discorremos o sexo, o local de trabalho e o tempo de atuação dos docentes que integraram a coleta de dados que ora descrevemos, a fim de identificá-los:

Tabela 1 - Quem são os entrevistados

\begin{tabular}{|c|c|c|c|}
\cline { 2 - 4 } \multicolumn{1}{c|}{} & SEXO & INSTITUIÇÃO & TEMPO DE MAGISTÁRIO \\
\hline PE 1 & Feminino & Escola Pública Municipal & 12 anos \\
\hline PE 2 & Feminino & Escola Pública Municipal & 17 anos \\
\hline PE 3 & Masculino & Escola Pública Estadual & 6 anos \\
\hline
\end{tabular}

Fonte - Tabela construída pelos autores (2021)

Observa-se, consoante aos dados extraídos da tabela, tratar-se de professores em momentos distintos da carreira, sendo que o PE 3, no que se refere à temporalidade, encontra-se na transição da iniciação da carreira para uma fase de estabilização, já a PE 1 localiza-se em uma fase intermediaria da profissão e a PE 2 aproxima-se do estágio de "maturidade docente", isto é, já experiente no exercício do magistério. A literatura especializada retrata que a problemática em torno da docência, enquanto profissão, suscita uma diversidade de compreensões (TENORTH, 1988; CAVACO, 1995; GIMENO SACRISTÁN, 1999; ALTET, s/d; BAILLAUQUĖS, 2001; CHAKUR, 2005).

Conquanto, se há certo consenso, ele recai sobre o fato de que, ao longo da trajetória profissional, os professores atravessam etapas, em outras palavras, vivenciam o "ciclo de vida profissional docente", conforme anota Hubernan (2000), sendo o mesmo organizado em fases que traduzem diferentes aspirações a respeito da profissão. Em linhas gerais, pode-se dizer que no início há a inserção do professor na carreira, ocasião na qual o professor neófito expressa medos, dúvidas, angústias e questionamentos; no decurso da mesma, percorre fases em que há certa distância entre os ideais e as realidades, o sentimento de libertação e 


\section{Authaดูã}

ISSN: 1984-6444 | http://dx.doi.org/10.5902/1984644442561

pertença, sensação de rotina e motivação elevada; e o encerramento desse ciclo é marcado por sentimentos como serenidade, conformismo e menos sensibilidade em relação à avaliação das outras pessoas.

Vale ainda destacarmos que, as fases do ciclo de vida docente acima aludida, não são lineares, não raro, manifestam-se de modo concomitante ou com alguma antecipação, tal como no cenário educacional brasileiro. Ao que tudo indica as precárias condições de trabalho que incluem os baixos salários, a dupla e até tripla jornada de trabalho, igualmente, a falta de recursos materiais nas escolas, infraestrutura deficitária e número alto de alunos por turma são elementos que interferem no ciclo de vida docente (OLIVEIRA, 2010).

$\mathrm{Na}$ tabela 2, tem-se o perfil formativo dos docentes que compuseram a pesquisa.

Tabela 2 - Perfil formativo dos docentes entrevistados

\begin{tabular}{|c|c|c|c|c|c|}
\cline { 2 - 6 } \multicolumn{1}{c|}{} & $\begin{array}{c}\text { FORMAÇÃO } \\
\text { INICIAL }\end{array}$ & INSTITUIÇÃO & $\begin{array}{c}\text { ANO DE } \\
\text { CONCLUSÃo }\end{array}$ & $\begin{array}{c}\text { FORMAÇÃO } \\
\text { COMPEMENTAR }\end{array}$ & $\begin{array}{c}\text { ANO DE } \\
\text { CONCLUSÃo }\end{array}$ \\
\hline PE 1 & $\begin{array}{l}\text { Licenciatura em } \\
\text { Educação Física }\end{array}$ & Privada & 2006 & $\begin{array}{c}\text { Especialista em } \\
\text { Educação Física } \\
\text { Escolar }\end{array}$ & 2016 \\
\hline PE 2 & $\begin{array}{l}\text { Licenciatura em } \\
\text { Educação Física }\end{array}$ & Privada & 1998 & $\begin{array}{c}\text { Psicomotricidade } \\
\text { e Educação Física } \\
\text { Adaptada }\end{array}$ & Não informou \\
\hline PE 3 & $\begin{array}{c}\text { Licenciatura em } \\
\text { Educação Física }\end{array}$ & Pública & 2013 & -------- & -------- \\
\hline
\end{tabular}

Fonte - Tabela construída pelos autores (2021)

Depreende-se do conteúdo da tabela que a PE 1 e PE 2 são oriundas de instituições privadas, enquanto que o PE 3 advém da instituição pública. Quanto a isso vale distinguir o escopo pensado no âmbito da formação em instituições de educação superior privadas, na maior parte dos casos, subordinado aos ditames do mercado profissional, algo que, por efeito, torna escassa a presença da pesquisa e da extensão. A esse respeito Demo (2008, p. 40) adverte: "quem não pesquisa, não pode ensinar. Essa ideia não desvaloriza habilidades didáticas, nem mesmo algumas tradicionais, como saber expor as ideias, usar bem a lousa, entoar 


\section{Autharẫ}

ISSN: 1984-6444 | http://dx.doi.org/10.5902/1984644442561

adequadamente a voz, etc.". E complementa, explanando "importante começar do começo; do começo está a pesquisa, não a aula" (DEMO, 2008, p. 40).

À vista do lugar de ocupação da pesquisa na formação docente, algumas considerações - ainda que lacônicas - a respeito dos desígnios formativos que contornam as instituições públicas e privadas merecem ser debatidas, sem desconsiderarmos os limites contextuais (e textuais) que afetam nosso estudo.

Pois bem, no âmbito das dimensões formativas ofertadas pelas referidas instituições, devemos considerar que nas IES ao abrigo da administração pública concentram-se a maior parte da produção de pesquisas no país, por efeito, subsidiam ensino e as práticas extensionistas - ao menos em tese -, tendo em vista o ideal de indissociabilidade entre a tríade (ensino, pesquisa e extensão). Por outro lado, as instituições privadas não acompanham essa tendência de produção epistêmica, visto que são afetadas pelas ingerências de mercado, a julgar pela transformação de um número significativo delas em grandes empresas, haja vista a multiplicação de seus campi e do crescimento de matrículas em vários estados e regiões do país. Na prática, elas (lê-se as IES privadas), na maior parte dos casos, não acompanham as inovações cientificas (filosóficas e artísticas), tampouco nutrem (epistemologicamente) ou zelam pela qualidade do ensino, de igual modo pela extensão, excetuando algumas exceções cujo valor investido é alto para preservarem a tríade (BARRETO, 2015).

Há ainda, no interior dessa conjuntura, outro imbróglio, refere-se à expansão dos cursos de educação à distância, cujas propostas, em geral, apresentam fragilidades e inconsistências em suas propostas curriculares, seja em relação à infraestrutura e o acompanhamento acadêmico/profissional dos estudantes, seja em razão dos índices de absenteísmo. Somam-se a isso, outras questões que afetam a qualidade da formação (docente) ofertada, suscitando muitas desconfianças e preocupações (BARRETTO, 2011).

$\mathrm{Na}$ continuidade da investigação, propomo-nos a mapear as trajetórias formativas dos docentes pesquisados, interpelando-os quanto aos impactos da formação (inicial) no desempenho da profissão docente, vejamos os depoimentos: 


\title{
T Hsy

ISSN: 1984-6444 | http://dx.doi.org/10.5902/1984644442561

[aprendem], assim como não explicam o desenvolvimento de tal conhecimento levando em conta as suas experiências passadas e presentes".

Por efeito, inquirimos os docentes pesquisados, quanto à influência da formação inicial para o desenvolvimento do ensino da Educação Física (considerando a planificação, os conteúdos, a forma de condução pedagógica e a avaliação), tendo em vista a realidade na qual se encontram as instituições em que exercem a docência, vamos às respostas:

\begin{abstract}
Então, como o meu foi Licenciatura Plena, acho que o tempo de estágio foi curto, as aulas deveriam ser mais específicas em cada etapa da educação básica. Isso faz falta quando chegamos à escola para dar aula. Não, eu não tive [uma formação que contemplou] todos os conteúdos [tais como]: esporte, ginástica, danças. Então, nesse sentido, eu acho que não [contemplou]. (PE 1);

Sim, lutas, por exemplo, como já expliquei anteriormente. A instituição era confessional, não podendo haver contato físico, razão pela qual se dividia a turma em algumas atividades destinadas às mulheres e outras aos homens. (PE 2).
\end{abstract}

São respostas que identificam fragilidades na formação inicial, inclusive, vale frisar, em razão de marcadores religiosos que afetaram, de certa maneira, o processo formativo. Por sua vez, o PE 3, ao responder esta mesma indagação revela que sua formação possuiu algo específico em relação às demais, observemos, pois, suas palavras:

\footnotetext{
Sim, vários conteúdos. Na dança vejo que há limitações, com as lutas houve muitas, atividades rítmicas, outras culturas, como, por exemplo, a cultura circense. Embora estivessem previstas no currículo os conteúdos eram limitados. A formação ocorre basicamente em função do esporte, portanto, o restante aparece sempre com limitações. Ou então, como um elemento de promoção à saúde, para 'educação do físico.' (PE 3).
}

Ao que tudo indica estamos diante do cenário já advertido por Demo (2008, p. 39), em que "as licenciaturas, por meio das quais se formam os docentes de áreas específicas da educação básica, possuem problemas, a começar pela mistura indigesta de bacharelado e licenciatura". Complementa ainda o aludido autor que: " não se faz nenhum dos dois de maneira minimamente aceitável" (DEMO, 2008, p. 


\section{T uss

ISSN: 1984-6444 | http://dx.doi.org/10.5902/1984644442561

39).

A propósito do mote, as educadoras norte-americanas Lampert e Ball (1999) apresentam uma análise negativa da formação inicial de professores, pois, sob o escrutínio delas, a origem dos problemas reside nos seguintes fatores: (1) pensar que o que é preciso para ensinar consiste em pouco mais do que o senso comum, isto é, não mostrar a necessidade de um conhecimento profissional; (2) não atender às concepções, às crenças e aos conhecimentos que os candidatos a professores trazem para a formação inicial; (3) separar a prática e a teoria, tanto fisicamente como conceitualmente, sendo a teoria raramente refletida na prática e a prática pouco interrogada pela teoria; (4) não valorizar devidamente o conhecimento didático; e (5) dar pouca importância à prática profissional. Ao que parece, as narrativas dos depoentes - notadamente PE 1 e PE 3 - ratificam as fragilidades identificas pelas pesquisadoras, em especial no que concerne aos dois últimos aspectos.

Houve ainda, no interior desse cotejamento concernente à formação, o interesse em desvelar as motivações que levaram a escolha da carreira professoral, em outras palavras, as razões que induziram a escolha da profissão docente, em especial em relação ao componente curricular Educação Física. Como respostas, encontrarmos as seguintes narrativas:

Na verdade, eu entrei na Educação Física porque eu trabalhei com dança, desde pequena eu pratico. Entrei no curso por conta dela, mas aí eu me tornei professora em escola mesmo. (PE 1);

Fiz essa escolha por paixão. Sempre gostei muito dessa área, mas não era algo que eu planejei. Isso "aconteceu" quando começou a existir o curso em Lavras/MG. Na realidade eu analisava e tinha muito interesse, mas nessa época eu já me encontrava casada, e com filhos. Após algum tempo, por um motivo maior, precisei voltar a fazer alguma atividade como forma de terapia, então eu escolhi adentrar a faculdade, e eu queria o curso de Educação Física que por suposto já era de meu interesse. A partir disso, consegui concluir minha graduação. (PE 2); 


\section{T Us:m \\ 7 ISSN: 1984-6444

ISSN: 1984-6444 | http://dx.doi.org/10.5902/1984644442561

Escolhi ser professor, por efeito da Educação Física. Não sei se eu seria professor de outra área. Havia em mim, algumas dúvidas em ser professor de história, mas não foi uma coisa que engrenou, que prosseguiu e que eu busquei, me encaminhei mais para a área da Educação Física por conta do esporte. Jogava basquete, pratiquei esporte a vida toda, treinei bastante, desde então decidi ir, eu sempre tinha a ideia de não ser treinador, nunca tive essa pretensão de trabalhar com o esporte em clubes, e dentre outras coisas do tipo. Minha intenção era de ser professor em escola mesmo, mas o que me levou foi o esporte. (PE 3).

Observando os relatos, é possível afirmar que a motivação para a escolha da Educação Física, enquanto profissão, advém, em grande medida, de experiências precedentes em relação às práticas corporais, em especial as de natureza esportiva, conforme anotaram PE 1 e PE 3. Lembremos que a identidade profissional caracteriza-se na forma pela qual os professores definem a si mesmos e aos outros. Refere-se à construção do seu eu profissional, o qual se desenvolve ao longo da carreira docente, sendo, portanto, influenciada por um conjunto de variáveis, desde pessoas inspiradoras, a escola na qual leciona, até mesmo o contexto político que demarca "o compromisso pessoal, a disponibilidade para aprender a ensinar, as crenças, os valores, o conhecimento sobre as matérias que ensinam e como as ensinam, as experiências passadas, assim como a própria vulnerabilidade profissional"; as identidades profissionais, nesse sentido, configuram-se por um "complexo emaranhado de histórias, conhecimentos, processos e rituais" (LASKY, 2005, p. 904).

Conquanto, a participante PE 2 traz outro fator à baila, embora não revele na totalidade, alude que sua motivação guarda relação com um tratamento (terapia). Merece destaque em sua fala, além disso, o fato de ter iniciado sua formação tardiamente em virtude de suas escolhas pessoais, algo que, em alguma medida, revela traços de uma sociedade marcadamente patriarcal que sutilmente atribui papeis distintos às pessoas, razão pela qual não é possível falar em equidade de oportunidades, dado que elas passam pela clivagem de: gênero; raça; classe social; dentre outras tantas classificações (LOURO, 1997). Na continuidade, tem-se a segunda categoria de análise. 


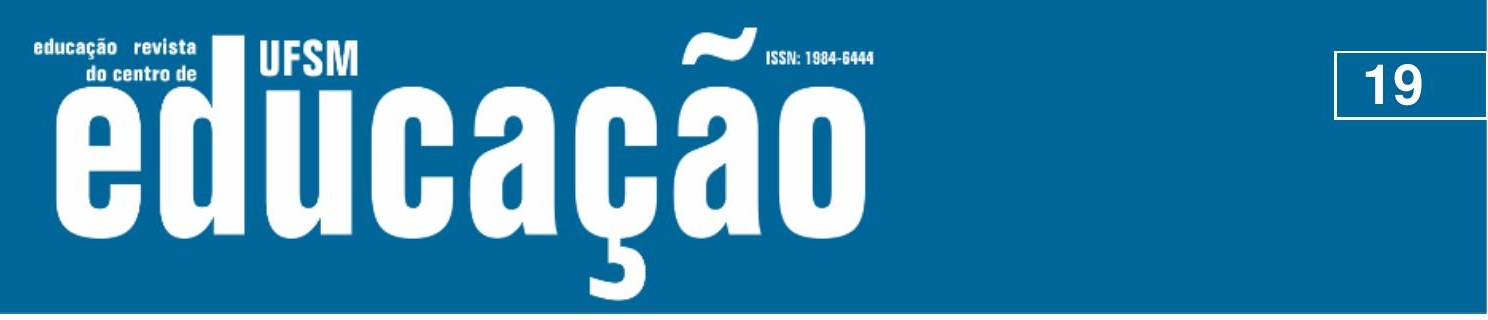

ISSN: 1984-6444 | http://dx.doi.org/10.5902/1984644442561

\section{Da implantação aos efeitos do Programa Residência Pedagógica nas instituições escolares em que atuam os docentes entrevistados}

Ao serem questionados sobre as implicações do PRP nas escolas em que atuam, os entrevistados responderam o seguinte:

Tem sido ótimo para a escola, os alunos ganharam muito, a instituição
adorou, tanto que apoiou muito o programa, na compra do que
precisávamos, na divulgação do trabalho pedagógico realizado. Ele
significou muito para todos, em minha vivência profissional se tratou de algo
diferente, visto que foram [desenvolvido] conteúdos que eu nunca havia
trabalhado, os efeitos chegaram até as redes sociais, sendo bastante
elogiado e as crianças, de modo geral, adoraram as aulas. (PE 1);

Sim, bastante, a própria interferência e presença dos residentes na escola. Isso causa mudanças, porque os alunos criam olhares diferentes, pelo próprio trabalho que os residentes estão realizando. Isso reflete na sala e na escola, pois os outros alunos não participantes do PRP, também interessam se perguntando acerca dos trabalhos realizados. (PE 2);

Digo que para a escola não sei, mas para o "sujeito" estudante sim. Não conseguimos ainda atrair de forma expositiva, a escola para os nossos projetos, mas, por exemplo, avistei um cartaz do PRP de Letras, supervisionado por uma professora. Ela fez um mural enorme na escola, e isso fez com que eu me interessasse em fazer algo parecido, desde então, juntamente com os residentes de meu grupo, pensamos em algo, pois possuímos muitos trabalhos e diversas fotos que poderiam ser expostos. Vejo que isso causa um impacto grande na escola, no entanto, por conta dessa ausência de trabalho expositivo, não conseguimos ter um impacto vindo da Educação Física, mas do ponto de vista das turmas, há um impacto muito grande. Também gera um impacto para as turmas que não são meus alunos, onde dividimos a quadra com eles. De alguma forma, gera impacto, eles olham e falam da seguinte forma: "poxa a gente queria estar fazendo isso aí", e consequentemente acaba gerando impacto também para a professora das outras turmas. (PE3).

Em linhas gerais, pode-se inferir que o PRP apresentou efeitos (auspiciosos) no interior das unidades escolares, alcançando até o universo das redes sociais, segundo a PE 1. De algum modo, o programa afetou a dinâmica da escola, seja em razão da presença dos professores em formação (cognominados de residentes), seja na dimensão visual, como destacou o PE 3, ou mesmo no interior da disciplina de Educação Física, cujos efeitos despertaram o interesse de alunos/as não participantes das aulas. Efetivamente, seu impacto reverbera também em questionamentos pedagógicos para os demais docentes que não atuam no referido 


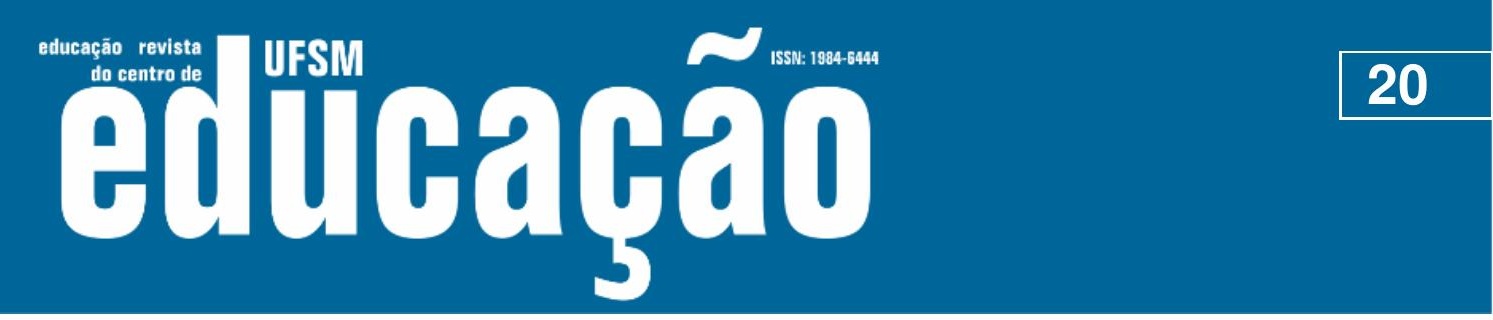

ISSN: 1984-6444 | http://dx.doi.org/10.5902/1984644442561

programa, um impacto - ou inquietação - indireto, por assim dizer.

Chama à atenção, o inicio da narrativa do PE 3, quando demove sua análise do eixo genérico da instituição, para observar os efeitos do referido programa na vida dos jovens, indivíduos esses que compõem o tecido institucional. Trata-se de um deslocamento analítico muito interessante, em certa medida, alinhado às preocupações de Dayrell (1996, p. 5):

Outra forma de compreender esses jovens que chegam à escola é apreendê-los como sujeitos sócio-culturais. Essa outra perspectiva implica em superar a visão homogeneizante e estereotipada da noção de aluno, dando-Ihe outro significado. Trata-se de compreendê-lo na sua diferença, enquanto indivíduo que possui uma historicidade, com visões de mundo, escalas de valores, sentimentos, emoções, desejos, projetos, com lógicas de comportamentos e hábitos que lhe são próprios.

$\mathrm{Na}$ direção de elucidar melhor os efeitos do programa, indagamos os entrevistados se haveria algum acontecimento que retratasse pontualmente estes efeitos, vejamos os depoimentos:

Sim, no dia em que fizemos exposição de fotos das atividades do circo, os pais chegaram para ver 0 mural, por efeito comentavam que o projeto deveria ser realizado com a escola inteira e não somente com Educação infantil. Até a própria diretora e coordenadora mencionaram que deveríamos pensar para o próximo ano, um projeto com todos, pois foi muito envolvente. (PE 1);

Eu não saberia responder essa questão, porém observa-se no geral, mas que esteja acontecendo algum evento, não sei te dizer. (PE 2);

Existem duas avaliações em minha opinião, que são muito significativas. De uma aluna do segundo ano $\mathrm{C}$ onde ela responde sobre jogos e brincadeiras: "Talvez se as crianças e jovens do meu bairro brincassem mais com esses jogos na rua, talvez diminuíssem o número de brigas na escola", e outra de um aluno do terceiro $\mathrm{B}$, respondendo sobre o handebol e as metodologias de jogos, onde ele dá importância descrevendo sobre o jogo como forma de ensinar, do sair de algo mais simples para o mais complexo, daquilo que aparenta não fazer sentido e chegar ao jogo de Handebol. Eles conseguiram ter essa percepção. Outra coisa é a própria fala de alunos das outras turmas. Certa ocasião executei com eles um jogo que não tinha nada a ver com o bimestre, porém foi muito interessante e proveitoso, as alunas que estavam de fora, na outra aula de Educação Física que não era minha, observavam enquanto meus alunos jogavam e diziam: "nossa, um jogo simples que só a organização faz com que a gente queira entrar, participar e querer jogar", esses comentários das turmas ouço bastante, e essa em especial foi significativa. (PE 3). 


\section{N

ISSN: 1984-6444 | http://dx.doi.org/10.5902/1984644442561

Com exceção da resposta da $\mathrm{PE} 2$, os exemplos trazidos à tona pelos demais docentes traduzem bem os efeitos do referido programa. Pois bem, ainda nessa esteira de análise, quisemos saber quais foram os entraves e as dificuldades na implantação do PRP e no seu desenvolvimento. Doravante, têm-se as narrativas:

Não houve nenhum entrave ou desafio, a diretora é muito flexível, e me deu apoio dizendo que seria muito bom, pois já havia participado de trabalhos vinculados à universidade, então houve total apoio. (PE 1);

Não, o PRP adentrou com uma boa aceitação, a imersão e inserção na escola foi tranquila, foram bem recebidos, nesse sentido, realmente não houve transtornos. (PE 2);

Não, acho que não houve entraves, a escola já está acostumada, desde que o PIBID começou na universidade, aqui sempre teve projetos, então eles já estão acostumados com esse tipo de intervenção muitos alunos trabalhando é normal para eles, tínhamos um grupo de quatro residentes, mas há professores que trazem dez de uma vez só. Acontece de haver mais estagiários do que alunos na sala de aula. Então a escola já está aberta para isso, os alunos estão muito acostumados com estagiários. Eles já possuíam a ideia da metodologia, de que precisam se adequar, ajudar conforme for organizado. (PE 3).

Em linhas gerais, constatamos, com base nos depoimentos, que, desde a implantação ao desenvolvimento o programa fora exitoso, uma conjuntura atípica, se considerarmos os desafios que envolvem a inserção de políticas pública de formação, coadunando duas instituições formativas que dispõem de conformações organizacionais distintas. Nesse sentido,

nota-se atualmente, alguns esforços de interlocução entre as diferentes instâncias de formação docente. Movimentos que sinalizam, por exemplo, aproximações entre a universidade e a escola, alvitrando à melhoria na qualidade da educação em suas diferentes etapas do ensino. (SILVA, et al., 2017, p. 67).

A seguir, passaremos para terceira e última categoria de análise, nela alvitramos aferir as implicações do programa na formação (continuada) e na organização do trabalho pedagógico dos pesquisados. 


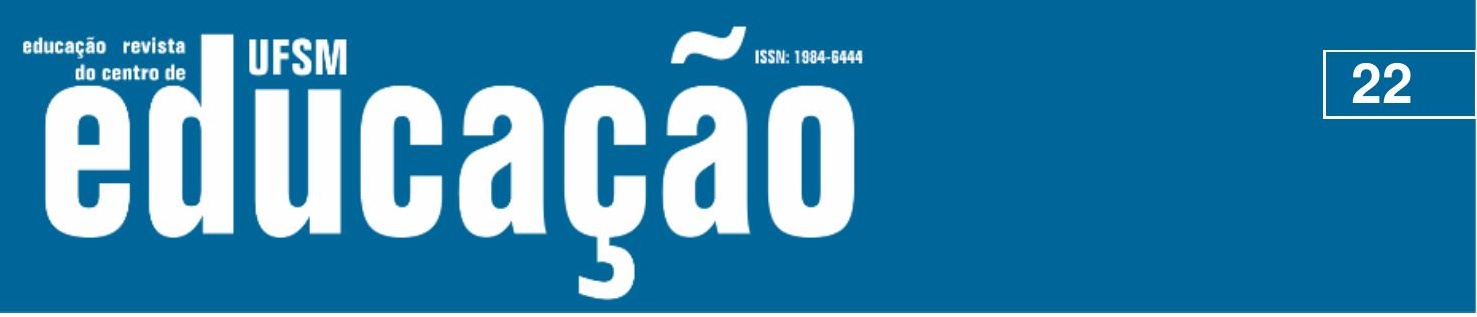

ISSN: 1984-6444 | http://dx.doi.org/10.5902/1984644442561

\title{
As implicações do PRP para a formação (continuada) e a \\ organização do trabalho pedagógico nas aulas de Educação Física
}

No interior dessa categoria, campeamos compreender, primeiramente, as razões pelas quais os docentes que participaram da pesquisa optaram por participar do PRP. Na sequência, examinamos os relatos.

\begin{abstract}
Eu me formei já há algum tempo, e depois disso eu passei no concurso e fiquei sem me atualizar, porque eu me casei, fui cuidar de casa e ter filhos, então acabou que eu fiquei naqueles cursos que a secretaria oferece, então quando eu fiquei sabendo do PRP, eu já tinha uma ideia do PIBID por ouvir outros professores que participavam, então eu pensei que seria legal, além do atrativo da bolsa, claro, mas achei que seria importante participar, como forma de ter o contato com a universidade, com outros professores. (PE 1);

[...] pelo fato de eu ter participado do PIBID, no entanto, posteriormente veio a oportunidade de me inserir ao PRP. Automaticamente eu mudei, mas eu não saberia distinguir os dois programas, embora o PIBID, hoje em dia posso dizer, tenha sido uma experiência menos eficiente do que o PRP. Acredito que o PRP está sendo mais completo, o programa é mais amplo e a atuação dos residentes também. (PE 2);

Por dois motivos, o primeiro foi por efeito da bolsa, pois analisando o nosso salário, ela se torna significativa e o outro seria por continuar a formação. Do ponto de vista epistemológico me afetou muito e me trouxe para a teoria, para a concepção de "Educação Física", me ajudou a sintetizar isso, organizar, do ponto de vista do planejamento, enfim, principalmente do ponto de vista da síntese (o que é, por que, de onde vem). Isso interferiu na prática, na organização do trabalho pedagógico e nas escolhas didáticas. (PE 3).
\end{abstract}

É possível extrairmos dos depoimentos alguns elementos relevantes, sendo um deles a questão do apoio financeiro, notadamente, porque, no Brasil, as difíceis condições de trabalho, os baixos salários, a dupla e até tripla jornada de trabalho, a falta de recursos materiais nas escolas, a infraestrutura precária e o número excessivo de alunos por turma são alguns dos elementos que contribuem para que professores (potenciais e exercício) declinem da carreira. Portanto, os PE 1 e PE 3, ao aludirem a escolha em participar do PRP em virtude da bolsa, indicam a necessidade de que a remuneração docente precisa ser devida considerada, basta ver o desprestígio que engendra à profissão docente, tendo em conta o fato do status social estar relacionado ao poder econômico (PIOLLI, 2015; LÜDKE e 


\title{
XI Hism Aitlbarat

ISSN: 1984-6444 | http://dx.doi.org/10.5902/1984644442561

BOING, 2004). Seus efeitos, de acordo com Sella (2006), impactariam, imediatamente na motivação e autoestima dos profissionais.

Outro aspecto que merece destaque diz respeito aos lastros formativos advindos de outro programa, caso do Programa Institucional de Bolsa de Iniciação à Docência (PIBID), dado que a PE 2 interessou-se pelo PRP em razão da experiência pregressa no programa supracitado (SILVA et al., 2017).

Por fim, compete-nos sublinhar, além do mais, o efeito do PRP em relação à dimensão epistemológica para compreensão da Educação Física, conforme salienta em seu depoimento o PE 3. Trata-se de uma repercussão extremamente significativa, a julgar pelos aditamentos formativos aos quais faz alusão.

Pois bem, nessa esteira de reflexão também cotejamos, junto à literatura científica, as implicações do PRP na formação (continuada) dos docentes que participaram da pesquisa. Observemos as respostas.

\begin{abstract}
Sim, e muito, nós preceptores conversamos o tanto que modificou a nossa forma de enxergar, por exemplo: eu mesma, igual todo mundo fala que as aulas de Educação Física são sempre as mesmas, mas não, eu nunca repeti as minhas aulas, eu sempre trabalhei mais com jogos e brincadeiras, mas eu não tinha um planejamento certo, uma organização do trabalho pedagógico, então o PRP me fez ter essa visão. Contam também os aspectos epistemológicos da área, de ter que ler os artigos, me ajudou muito. (PE 1);

Sim, o conhecimento no geral, pois a minha formação acadêmica não é recente, portanto, com o PRP eu tive oportunidade de atualização, de ficar mais próxima da universidade. (PE 2);

Do ponto de vista da didática não muito. Penso que eu mantive meu jeito "apegado", de gostar de falar com todos em um tom alto e de me envolver de fato com os alunos. Portanto, do ponto de vista didático nem tanto, mas há influências. (PE 3).
\end{abstract}

Ao que tudo indica, o PRP contribuiu para a formação dos professores que participaram da pesquisa, pois se trata de uma ilação admissível tendo em vista o teor narrativo da PE 1 e PE 2, ao destacarem que a formação (continuada), sobrevinda da referida participação, permitiu colmatar algumas fragilidades presentes na formação inicial e conferiu atualização epistemológica. Para elucidar 


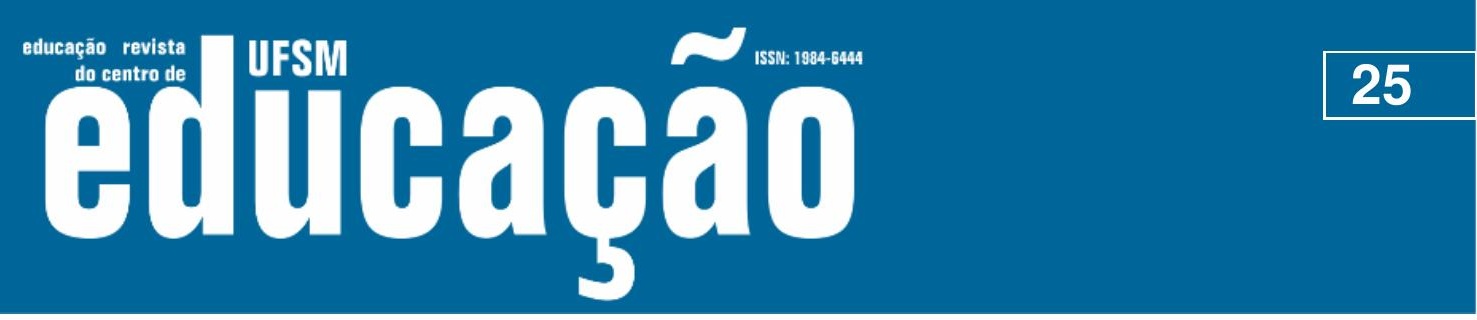

ISSN: 1984-6444 | http://dx.doi.org/10.5902/1984644442561

Não seria uma crítica, seria uma sugestão, pois ficaria interessante ficar na escola com o mesmo grupo por pelo menos um semestre no mínimo. E naquela parte de leitura dos artigos, para os residentes talvez tenha ficado muito repetitivo, visto que isto já havia sido tratado em aula, mas para os preceptores foi muito interessante; durante as reuniões dos participantes do PRP, nós já deveríamos estar com os planejamentos prontos, ficou muito corrido ter que planejar e começar a dar aula na outra semana. (PE 1);

Não, porém, acredito que eu valorizaria mais a prática [imersão na instituição escolar]. Não excluindo a necessidade da teoria, mas deveria haver uma forma mais "prática" para se discutir as questões da Educação Física. (PE 2);

Não há críticas de minha parte ao programa e nem da forma que ele foi organizado, apenas, talvez ao envolvimento dos residentes no programa, visto que eles poderiam estar mais próximos. (PE3).

O depoimento da PE 1 sugere que o rodízio realizado entre os discentes, nas etapas de ensino, deveria ser repensado, o que em parte é aceitável, visto que a mudança de grupos engendra desafios de ordem cronológica e organizacional, incidindo, por sua vez, na organização do trabalho pedagógico. Entretanto, a não realização desse rodízio incidiria na diminuição de experiências para os aspirantes a docência, dado que, ao passarem pelas diferentes etapas de ensino, ampliam o cabedal de conhecimento, ao menos em tese.

Outro aspecto que a PE 1 expõe refere-se ao contato com a teoria durante o processo formativo no PRP, a despeito de aparentar certa "repetição" sob a percepção de alguns residentes, em virtude daquilo que eles já vivenciavam nas disciplinas pertencentes ao currículo de formação inicial, revisar conceitos, além de recomendável, faculta a possibilidade de consolidar entendimentos e concepções epistemológicas. Por outro lado, tratou-se de um aprofundamento teórico importante para os preceptores, com efeito, revela o desafio de coadunar as duas extremidades da formação. A esse respeito Demo (2008, p. 11) adverte que, "teorias são feitas para usar, desconstruir e reconstruir, sendo fundamental evitar fazer delas bengalas mentais que, em geral, não possuem efeito prático". Ao que tudo indica, faltou essa condição de ressignificação teórica da parte dos residentes, em todo caso, trata-se de uma situação compreensível, em razão de estarem iniciando a jornada docente, até porque se espera "ler um autor para tornar-se autor, não porta-voz", adverte (DEMO, 2008, p. 11). 


\section{Autนaดูลิ}

ISSN: 1984-6444 | http://dx.doi.org/10.5902/1984644442561

Adquire proeminência também, na narrativa da PE 2, a suposição de uma dicotomia entre teoria e prática na dinâmica do PRP, contudo, sabemos que essa relação é indissociável. Há certa contradição na formação de professores - tanto na inicial, quanto na continuada - que incide em apregoar a existência de tal separação, quando, na realidade, as investigações sobre formação de docentes têm sinalizado para superação dessa acepção, observando o professor como produtor e mobilizador de saberes.

Ao abrigo dessa perspectiva, ele tanto absorve conhecimento, quanto se apropria e reconstrói conceitos, não apenas reproduz teorias já consolidas e sistematizadas, na condição de um operário do saber. Por sua vez, ao reelaborar o sentido do conceito, volta-se para as necessidades de sua intervenção, observando o espaço/tempo do trabalho pedagógico que desenvolve e as demandas da aprendizagem discente, de modo que se tece um saber que lhe é próprio, autoral por assim dizer, próximo à ideia de uma epistemologia da prática (TARDIF 2000; 2002).

Ora, não havendo dicotomia entre teoria e prática, mas sim uma esperada articulação, faz-se imperativo pensarmos a qualidade dessa relação, dado que ela permanece sob os cuidados da ação docente. Dessa maneira, será preciso que o docente ofereça dinamicidade ao ensino, transformando o conhecimento de conteúdo em conhecimento pedagógico do conteúdo; de igual modo que coordene a organização do trabalho pedagógico em sala de aula, ao ponto de desencadear (conflitos cognitivos e éticos) ao longo do processo de apresentação dos saberes, ao passo de fomentar sentido e significado à aprendizagem, tanto no plano dos conceitos quanto na esfera dos procedimentos (SHULMAN, 2014; MEIRIEU, 2005).

Ser professor compreende, para além dos elementos específicos de uma determinada área ou componente curricular, a aprendizagem dos aspetos do como ensinar e de que maneira inserir-se no espaço educativo escolar e na profissão docente (PONTE et al., 2000). Em última análise, espera-se que a formação "desenvolva a capacidade reflexiva nos professores, contribuindo para se tornarem profissionais responsáveis, autônomos e eticamente exigentes, sendo capazes de 


\section{N

ISSN: 1984-6444 | http://dx.doi.org/10.5902/1984644442561

refletirem eficazmente sobre a sua prática pedagógica" (OLIVEIRA \& CYRINO, 2011, p. 111).

Por fim, nessa sequência de aferição a respeito dos efeitos do PRP, inquirimos os docentes que integraram a pesquisa sobre a existência de algum outro aspecto pessoal ou institucional que gostariam destacar. Vejamos o que relatam:

Foi de grande valia para a escola, para meu trabalho pedagógico, e para os alunos de modo geral. Desconfio que para os residentes também. Seria muito importante esse programa de residência continuar e abarcar todos os professores de Educação Física, de maneira que pudessem vivenciar e tivessem a oportunidade de fazer parte do programa, acho que a Educação Física mudaria muito, principalmente o olhar para com ela, porque considero que foi muito interessante e importante, eu estava conversando com o outros preceptores, e comentamos o tanto que a gente mudou o nosso ponto de vista, o modo de pensar a disciplina e de como dar as aulas, eu acho que impactou bastante, e se todos tivessem a oportunidade seria diferente. (PE 1);

O que eu achei bem interessante foi na questão mencionada anteriormente, sobre o que difere o estágio supervisionado do programa de Residência Pedagógica que são bem distintos, e não são dignos de serem comparados. (PE 2);

Acredito que não. As perguntas mencionadas foram muito boas, e conseguiram até dar um percurso do que foi o programa, do ponto de vista epistemológico, metodológico, na intervenção, enfim, eu só tenho a agradecer ao PRP e a todos vocês. (PE 3).

Acreditamos que as narrativas expressem, por si só, o modo como o PRP afetou a formação dos participantes. Entretanto, o único ponto que julgamos oportuno frisar diz respeito à comparação entre o Estágio Supervisionado e PRP segundo a percepção da PE 2. Dado a relevância que promove o mote, outras investigações serão necessárias para analisar a pertinência de tal comparabilidade

A seguir, passaremos as considerações finais, expondo nossas impressões em relação à pesquisa.

\section{Considerações finais}

O estudo revelou certa idiossincrasia no que diz respeito ao trabalho pedagógico desenvolvido pelo núcleo da Educação Física, haja vista os resultados auspiciosos aqui expostos, indicando, com isso, que a planificação proposta para o 


\section{Autharão}

ISSN: 1984-6444 | http://dx.doi.org/10.5902/1984644442561

programa fora eficaz. Muito embora o trabalho pedagógico tenha sido exitoso, sua análise, ao deter-se tão somente aos depoimentos e não recorrer a outras fontes empíricas, evidencia uma limitação metodológica, notadamente em razão de seu tamanho amostral (3 docentes), não em virtude apenas da expressão numérica em si - visto que se trata de uma pesquisa assentada segundo os pressupostos qualitativos, sob um desenho narrativo -, mas por retratar experiências que nem sempre poderão ser representativas ou reaplicadas em outros espaços de formação. Ao mesmo tempo, sua singularidade poderá ser observada com "bons olhos" - a propósito, lembremos da orientação de Saramago (1995, p. 9), ao evocar que "se podes olhar, vê. Se podes ver, repare" -, dado que explicita movimentos próprios da interação dos docentes em exercício e em formação continuada, com os discentes em processo de formação inicial na constituição da práxis, sob o escrutínio das duas dimensões formativas, a saber: a universidade e a instituição escolar.

Com relação ao PRP de fato, podemos afiançar, por efeito dos resultados da pesquisa, que o mesmo fora desenvolvido segundo as normativas previstas pelo órgão regulador, no caso a Capes, ao menos no tocante ao núcleo Educação Física na IES. Contudo, também desenvolveu mecanismos próprios de funcionamento, a exemplo da participação de três docentes das IES dividindo a coordenação do PRP, quando o regimento exigia dois, igualmente em relação à articulação com outro programa de natureza semelhante, o Pibid, conforme já citado.

Em relação às características dos docentes que participaram da pesquisa, suas respectivas formações e motivações para o ingresso no PRP evidenciaram os seguintes traços: encontram-se em fases diferentes tendo em vista o "ciclo de vida profissional docente", consoante a acepção de Huberman (2000, p. 47); de igual modo revelam trajetórias formativas distintas para escolha da profissão docente em Educação Física; notamos, além disso, que a inserção na dinâmica que envolve o ensino, a pesquisa e a extensão - encontrada substancialmente nas IES públicas e fortuitamente nas IES privadas - incidiu nas experiências dos docentes ao longo da formação continuada; o estudo demonstrou ainda que a motivação para o ingresso na profissão docente adveio, em geral, não em decorrência das especificidades que 


\section{Autนaดูลิ}

ISSN: 1984-6444 | http://dx.doi.org/10.5902/1984644442561

são próprias do magistério, mas, sim, de experiências pregressas relacionadas às prática esportiva.

No que concerne à implantação e o desenvolvimento do PRP nas instituições escolares, constatou-se dinâmicas variadas, visto que as instituições, segundo o relato dos preceptores que participaram da pesquisa, foram afetadas de modo diferente, em comum a constituição de um círculo virtuoso que interferiu nas atividades escolares, na formação continuada dos próprios preceptores e na percepção sobre a importância de programas dessa natureza nas instituições escolares. Aliás, a aproximação entre as instâncias formativas, em nosso caso, a escola e universidade, a despeito de desafiadora, revela-se como um movimento alvissareiro para ambas.

Por fim, no que diz respeito à formação continuada dos preceptores e as implicações do PRP na e para organização do trabalho docente, cotejamos que a ideia de planificação das atividades docentes contida no processo formativo do PRP foi fundamental para uma espécie de reconceptualização pedagógica, fato que denota uma correlação positiva nas experiências escolares que a pesquisa examinou. Trata-se de um princípio epistemológico já retratado pela literatura científica, cujos efeitos engendram, por suposto, um desenvolvimento mais eficaz da ação docente, quando há planejamento.

Em que pese os limites do trabalho investigativo aqui exposto, espera-se assaz que o mesmo some-se a outros estudos, pelos quais se possa compreender a complexa relação de variáveis que afetam a formação docente - tanto a inicial quanto a continuada -, com isso se possa aprimorá-la.

\section{Referências}

ALTET, Marguerite. "Qual a formação profissionalizante para desenvolver as competências de "docente profissional" e uma cultura profissional de actor?». In TARDIF, Maurice; LESSARD, Claude; GAUTHIER, Clermont (Orgs.), Formação dos professores e contextos sociais. Porto: RÉS - Editora, 61 - 76, (s/d). 


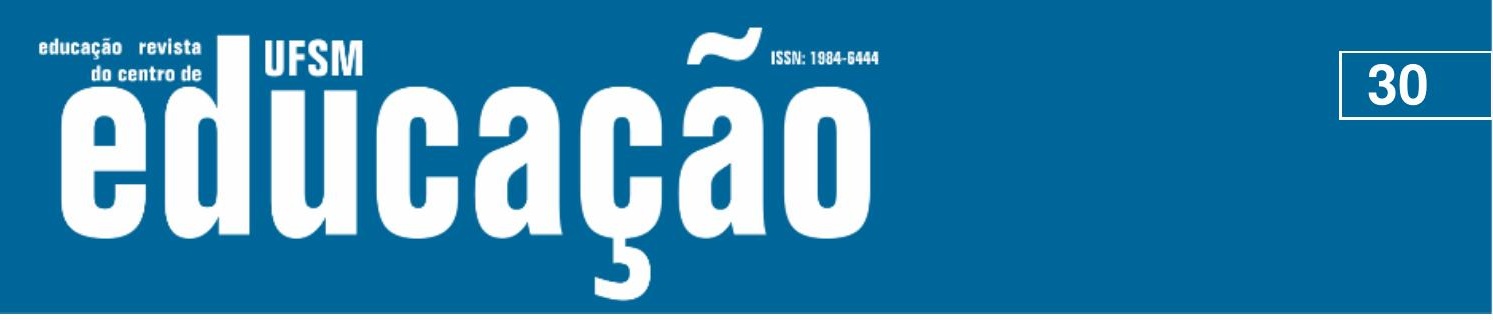

ISSN: 1984-6444 | http://dx.doi.org/10.5902/1984644442561

ALVARADO-PRADA, Luis Eduardo; FREITAS, Thaís Campos; FREITAS, Cinara Aline. Formação continuada de professores: alguns conceitos, interesses, necessidades e propostas. Revista Diálogo Educacional, Curitiba, v. 10, n. 30, p. 367-387, maio/ ago. 2010.

BARRETTO, Elba Siqueira de Sá. Políticas de formação docente para a educação básica no Brasil: embates contemporâneos. Revista Brasileira de Educação, Rio de Janeiro, v. 20, n. 62, p. 679-701, Sept. 2015.

BRACHT, Valter. A constituição das teorias pedagógicas da educação física. Cad. CEDES, Campinas, v. 19, n. 48, p. 69-88, Aug. 1999.

BULLOUGH, Robert; GITLIN, Andrew. Becoming a student of teaching: Methodologies for exploring self and school context. (2nd ed.). London: Routledge Falmer, 2001. Disponível em: http://dx.doi.org/10.1590/S010132621999000100005. Acesso em: 15 de fev. 2019

CAPES. Portaria capes $n=175$ de 7 de agosto de 2018. Disponível em: http://capes.gov.br/images/stories/download/legislacao/09082018-

Portaria_175_Altera_Portaria_45_de_2018.pdf. Acesso em: 28 de fev. 2019.

CAPES. Programa de Residência Pedagógica. Disponível em: https://capes.gov.br/educacao-basica/programa-residencia-pedagogica. Acesso em: 15 de nov. 2019.

CARVALHO, Anna Maria Pessoa de Carvalho. Os Estágios nos Cursos de Licenciatura. São Paulo/SP: Cengage Learning, 2017.

CAVACO, Maria Helena. Ofício do professor: o tempo e as mudanças. In: NÓVOA, António (Org.). Profissão professor. Porto: Porto Editora, 1995.

CHAKUR, Cilene Ribeiro de Sá Leite. O desenvolvimento profissional de professores das séries iniciais do ensino fundamental. Paidéia, Ribeirão Preto, v. 15, n. 32, p. 397-407. 2005.

COUTO, Ângela Maria Pinto. A Formação Inicial de Professores do Ensino Básico e a Geometria: Um estudo de dois casos. 2015. 395 f. Tese (TESE DE DOUTORAMENTO EM EDUCAÇÃO) - Departamento de Ciências da Educação e do Patrimônio, Universidade Portucalense, Porto, 2015.

CRESWELL, John W. Mapping the field of mixed methods research. Journal of Mixed Methods Research, 3(2), 95-108, 2009.

DAYRELL, Juarez. A escola como espaço sociocultural. In: DAYRELL, Juarez (Org.) Múltiplos olhares sobre educação e cultura. Belo Horizonte: Editora da UFMG, 1996.

DEMO, Pedro. Aprender bem/mal. Campinas, SP: Autores Associados, 2008. 


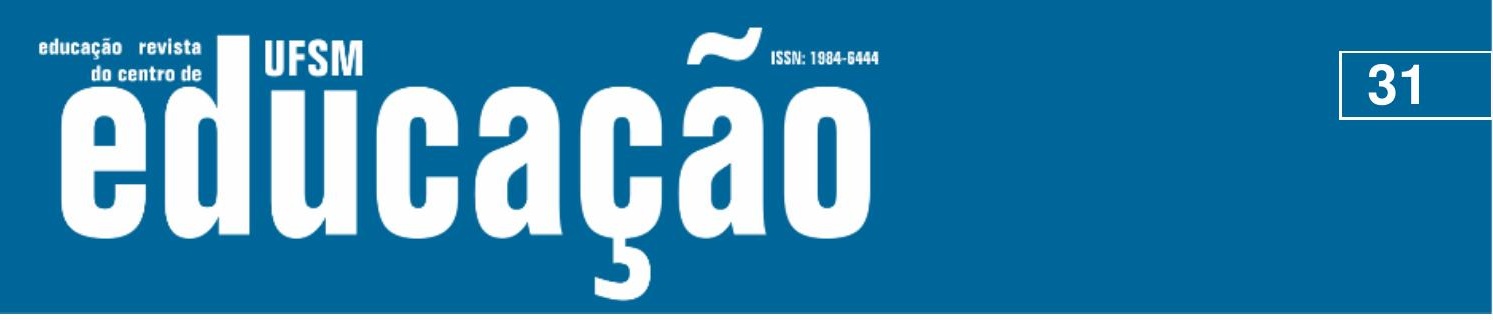

ISSN: 1984-6444 | http://dx.doi.org/10.5902/1984644442561

FEDERICI, Conrado Augusto Gandara. O que não é Educação Física. Movimento \& Percepção, Espírito Santo de Pinhal, SP, v.4,n.4/5, jan./dez.2004 - ISNN 16798678.

SACRISTÁN, José Gimeno. Consciência e acção sobre a prática como libertação profissional dos professores. In NÓVOA, Antônio (Org.), Profissão professor. Porto: Porto Editora, 1999, p. 63 - 92.

GOMES, Romeu et al. Organização, processamento, análise e interpretação de dados: o desafio da triangulação. In: MINAYO, Maria Cecília de Souza; ASSIS, Simone Gonçalves de; SOUZA, Edinilsa Ramos de (Org.). Avaliação por triangulação de métodos: Abordagem de Programas Sociais. Rio de Janeiro: Fiocruz, 2010. p. 185-221.

HUBERMAN, Michaël. O ciclo de vida profissional dos professores. In: NÓVOA, Antônio. (Org.). Vidas de professores. 2. ed. Porto: Porto, 2000. p.31-61.

LAMPERT, Magdalene; BALL, Deborah Loewenberg. Teaching, multimedia, and mathematics. Journal of Mathematics Teacher Education, 2 (3), 1999, p. 311-319.

LASKY, Sue. A sociocultural approach to understanding teacher identity, agency and professional vulnerability in a context of secondary school reform. Teaching and Teacher Education, 21, 2005, p. 899 -916.

LOUGHRAN, John. Developing pedagogy of teacher education: Understanding teaching and learning about teaching. London: Routledge, 2006.

LOURO, Guacira Lopes. Gênero, sexualidade e educação. Uma perspectiva pósestruturalista. Petrópolis: Vozes, 1997.

LUDKE, Menga; ANDRÉ, Marli Eliza Dalmazo Afonso. Pesquisa em educação: abordagens qualitativas. São Paulo, EPU, 1986.

LÜDKE, Menga; BOING, Luiz Alberto. Caminhos da profissão e da profissionalidade docentes. Educação \& Sociedade, Campinas, v. 25, n. 89, p. 1159-1180, set./dez. 2004. Disponível em: www.scielo.br/pdf/es/v25n89/22616. Acesso em: 7 maio 2019.

MEIRIEU, Philippe. O cotidiano da escola e da sala de aula. Porto Alegre: Artmed, 2005.

MINAYO, Marília Cecília de Souza (Org.). Pesquisa Social: teoria, método e criatividade. Petrópolis, RJ: Vozes, 2003.

MINAYO, Maria Cecília de Souza et al (Org.). Pesquisa social: Teoria, método e criatividade. Petrópolis, RJ: Vozes, 2010. 


\section{us: \\ ISSN: $1984-6444$}

ISSN: 1984-6444 | http://dx.doi.org/10.5902/1984644442561

SILVA, Mauro Sérgio; RACHT, Valter. Na pista de práticas e professores inovadores na Educação Física escolar. Kinesis, v. 30, n. 1, p. 80-94, 2012.

TARDIF, Maurice. Saberes profissionais dos professores e conhecimento universitário. Revista Brasileira de Educação, n. 13, 2000.

TARDIF, Maurice. Saberes docentes e formação profissional. Petrópolis, R.J.: Editora Vozes, 2002.

TENORTH, Heinz-Elmar. Profesiones y profesionalización: un marco de referencia para el análisis histórico del enseñante y sus organizaciones. Revista de Educación, 285, p. 77 - 92, 1988.

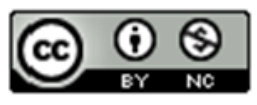

This work is licensed under a Creative Commons Attribution-NonCommercial 4.0 International (CC BY-NC 4.0)

\section{Nota}

\footnotetext{
1 Embora não seja o fito do estudo analisar os fundamentos epistemológicos, éticos, políticos e pedagógicos do referido documento, em linha gerias, pode-se afirmar que se trata de um documento normativo previsto pela Lei de Diretrizes e Bases da Educação Nacional (lei 9.394/1996) que "define" em seu artigo 26 (por suposto) o conjunto de aprendizagens essenciais aos alunos ao longo das etapas e modalidades da Educação Básica.
} 